\title{
Belajar dari Kasus RS Sumber Waras Ketika Kecakapan Profesional Auditor Offside
}

\author{
Sopian \\ Politeknik Keuangan Negara STAN \\ Sopian77@kemenkeu.go.id
} \begin{abstract}
pengungkapan dugaan tindak pidana korupsi. Untuk itu setiap
Reviewed: 05-03-17 akuntan forensik atau auditor investigatif diminta untuk menerapkan secara profesional standar pemeriksaan yang berlaku. Dengan metode deskriptif normatif, direkomendasikan agar audit investigasi Accepted: $25-04-17$

Published: 20-07-17 menjadi Jenis Audit terpisah dari Audit Tujuan Tertentu karena bertujuan mengumpulkan fakta dan bukti dan tidak memberikan kesimpulan atau opini atas hasil audit. Tujuan audit investigasi saat ini adalah memberikan simpulan atau pendapat dan ketika terjadi kolaborasi antara pencarian fakta dan bukti dengan pemberian pendapat yang melompati kecakapan profesional yang bukan menjadi kompetensi bidang pengetahuan seorang auditor maka terjadi kekeliruan terhadap opini yang diberikan.

Kata kunci : audit, fakta, korupsi, profesionalisme dan opini
\end{abstract}

\section{PENDAHULUAN}

Indonesia merupakan salah satu negara yang masih berkutat dengan persoalan pemberantasan korupsi. Berdasarkan data dari Badan Pusat Statistik (BPS), Indeks Perilaku Anti Korupsi (IPAK) pada tahun 2015 adalah sebesar 3,59 yang merupakan penurunan dari tahun 2014 sebesar 3,61 dan 3,63 pada tahun 2013. Indeks ini mengukur tingkat permisif masyarakat terhadap perilaku korupsi dengan cara survei persepsi dan pengalaman dalam hubungan dengan layanan publik yang berkaitan dengan penyuapan (bribery), pemerasan (extortion) dan nepotisme (nepotism). Rentang angka yang dipergunakan adalah skala 0 sampai dengan 5 .
Semakin mendekati angka 5 mengindikasikan bahwa masyarakat berperilaku semakin anti korupsi dan semakin mendekati angka 0 maka mengindikasikan bahwa masyarakat berperilaku semakin permisif terhadap korupsi. Dengan skor angka 3,59 mengindikasikan bahwa perilaku anti korupsi belum menjadi pola pikir dan kebiasaan yang baik bagi masyarakat.

Sebuah konsultan dan lembaga penyedia jasa intelijen bisnis dan politik yang berbasis di Hongkong, PERC (Political and Economic Risk Consultancy), memberikan penilaian tentang tingkat korupsi di Indonesia berdasarkan hasil risetnya khususnya yang berkaitan dengan suap menyuap (bribery) para pebisnis asing di Indonesia kepada para pimpinan bidang politik. 
Rentang skor yang dipergunakan adalah 0 untuk negara yang bebas korupsi dan 10 untuk negara yang sangat korup. PERC mengindikasikan bahwa Indonesia adalah salah satu negara yang memiliki skor tingkat korupsi tinggi yaitu 8.00 untuk tahun 2016 dan 8.09 untuk tahun 2015. Skor yang tidak jauh berbeda untuk tahun 2014 yaitu 8.85 dan 8.83 untuk tahun 2013. Indeks ini mengindikasikan bahwa Indonesia merupakan salah satu negara dengan tingkat korupsi yang tinggi di negara Asia.

Transparancy International menerbitkan Indeks Persepsi Korupsi (IPK) yang menggambarkan indikator tingkat korupsi sebuah negara secara lebih komprehensif. Dengan mengkolaborasi sepuluh sumber data dari lembaga internasional seperti Asian Development Bank, Economic Inteligence Unit dan Global Insight, Indeks Persepsi Korupsi Indonesia adalah 34 untuk tahun 2014 pada posisi urutan 107 dari 177 negara yang disurvei dan 36 untuk tahun 2015 meningkat menjadi posisi 88 dari 167 negara yang disurvei. Negara dengan skor mendekati 100 adalah negara yang relatif bersih dari korupsi dan negara yang mendekati skor 0 adalah negara dengan tingkat korupsi yang sangat masif dan tinggi. Indeks Persepsi Korupsi untuk Indonesia yang diterbitkan oleh Transparancy International sejalan dengan hasil survei persepsi korupsi yang dilakukan oleh Transparansi Internasional Indonesia (TII) pada tahun 2015. TII menyimpulkan bahwa korupsi telah secara nyata merupakan masalah bagi kemudahan berusaha, mendistorsi daya saing lokal, menurunkan integritas bisnis dan integritas publik serta menghambat program pemerintah untuk meningkatkan investasi melalui penerbitan paket kebijakan ekonomi.

Tindak pidana korupsi di bidang pengadaan barang dan jasa merupakan kasus korupsi yang dominan disidik oleh Komisi Pemberantasan Korupsi. Sejak KPK berdiri pada tahun 2003 hingga 2015, kasus pidana korupsi bidang pengadaan barang dan jasa berjumlah 138 dengan perkiraan kerugian negara berjumlah kurang lebih sekitar Rp 1 Trilyun di luar kasus suap menyuap yang berhubungaan dengan pengadaan barang dan jasa. Laporan tersebut juga mengutip hasil riset dari IPW (Indonesia Procurement Watch) yang menyimpulkan bahwa sekitar $93 \%$ pengusaha melakukan suap menyuap agar dimenangkan dalam tender proyek. Catatan KPPU (Komisi Pengawas Persaingan Usaha), dikutip dalam Laporan Kajian Direktorat Litbang KPK, menunjukkan bahwa selama periode 2006 - 2012 dari perkara persaingan usaha sebanyak 173 kasus, sekitar 97 perkara atau $56 \%$ berkaitan dengan persekongkolan tender pengadaan barang dan jasa.

Salah satu kasus yang berindikasi korupsi dan menarik perhatian masyarakat adalah pengadaan atau pembelian RS Sumber Waras yang dilakukan oleh Basuki Tjahaja Purnama (BTP) selaku Gubernur DKI Jakarta pada tahun 
2014. Kasus ini mendapat perhatian publik karena terdapat perbedaan pendapat antara hasil audit investigasi Badan Pemeriksa Keuangan dengan hasil penyelidikan Komisi Pemberantasan Korupsi. Secara prinsip, tidak banyak perbedaan metode investigasi antara audit tujuan tertentu atau audit investigatif dengan proses penyelidikan.

Tulisan ini dibuat dengan tujuan untuk

a. Memberikan penjelasan tentang peran dan fungsi akuntansi forensik dan audit investigasi atau audit tujuan tertentu dalam proses pengungkapan kejahatan kerah putih khsusunya korupsi

b. Memberikan gambaran tentang tujuan akuntansi forensik atau audit investigasi yang berlaku di Indonesia dan praktek terbaik di dunia internasional;

c. Menjelaskan dampak audit investigasi terhadap penegakan hukum khususnya korupsi dengan fokus pengungkapan dugaan korupsi pembelian RS Sumber Waras oleh Pemda DKI Jakarta.

Tulisan ini memiliki keterbatasan dalam hal sumber data primer. Penulis telah berupaya untuk memperoleh data primer dengan cara meminta salinan laporan hasil audit investigasi pembelian RS Sumber Waras kepada BPK. Respon yang diperoleh dari pihak BPK melalui Pusat Informasi dan Komunikasi adalah bahwa berdasarkan UU No 14 Tahun 2008 dan Peraturan BPK No 3 Tahun 2011 dinyatakan Laporan Audit Investigatif BPK adalah informasi yang dikecualikan sebagai informasi publik. Sumber analisa adalah tulisan di beberapa media yang mengulas tentang Proses Pengadaan RS Sumber Waras.

\section{KAJIAN TEORI}

\section{Tindak Pidana Korupsi}

Secara harfiah, korupsi menurut Muhammad Ali adalah perbuatan busuk yang suka menerima uang sogok atau suap, memakai kekuasaan untuk kepentingan pribadi. Transparansi Internasional Indonesia mendefinisikan korupsi sebagai segala bentuk penyalahgunaan wewenang untuk memperoleh manfaat atau keuntungan pribadi. Indriyanto Seno Adji (2012) berpendapat bahwa secara esensi tindak pidana korupsi adalah memperoleh kekayaan atau keuntungan untuk diri sendiri atau persekongkolan untuk orang lain atau korporasi. Sedangkan Bibit Samad Riayanto (2009) dalam laporan Litbang KPK mendefinisikan korupsi sebagai perbuatan melawan hukum atau penyalahgunaan kewenangan publik yang merugikan negara atau masyarakat dengan unsur niat melakukan korupsi (desire to act), kemampuan untuk berbuat korupsi (ability to act), kesempatan atau peluang untuk berbuat korupsi (opprotunity to corrupt) dan target atau sasaran untuk dikorupsi (suitable target)

Undang-Undang (Selanjutnya disingkat UU) Nomor 31 Tahun 1999 Jo UU No 20 Tahun 2001 tentang Tindak Pidana Korupsi secara jelas dan tegas mengatur tentang perbuatan yang 
masuk dalam delik korupsi di Indonesia. Secara

ringkas, tindak pidana korupsi dapat diklasifikasi

menjadi tujuh jenis yaitu

a. Yang berkaitan dengan kerugian negara dengan unsur perbuatan melawan hukum (pasal

2) atau penyalahgunaan kewenangan (pasal 3) untuk memperkaya atau menguntungkan diri sendiri atau orang lain

b. Suap atau pemberian janji kepada penyelenggara negara atau pegawai negeri diatur dalam pasal 5 (1) a dan b dan (2), pasal 6 (suap kepada hakim), pasal 11, pasal 12 a, b, c, d dan pasal pasal 13

c. Penggelapan dalam jabatan diatur dalam pasal 8, 9 dan $10 \mathrm{a}, \mathrm{b}$ dan $\mathrm{c}$

d. Delik Pemerasan diatur dalam pasal 12 huruf e, f, dan $g$

e. Delik perbuatan curang pasal 7 (1) a,bc, dan d dan pasal $12 \mathrm{~h}$

f. Delik benturan kepentingan diatur dalam pasal $12 \mathrm{i}$

g. Gratifikasi diatur dalam pasal 12B

Terdapat perbedaan pendapat dari para ahli hukum tentang definisi unsur penyalahgunaan kewenangan sebagaimana diatur dalam pasal 3. Adami Chazawi ${ }^{12}$ (2011) berpandangan bahwa setiap penyalahgunaan kewenangan, sarana atau kesempatan secara terselubung di dalamnya terdapat perbuatan melawan hukum karena pelaku tidak memiliki hak untuk berbuat yang menyalahi kewenangannya. Pendapat berbeda disampaikan oleh Indriyanto Seno Adji (2012) yang menyatakan bahwa penyalahgunaan kewenangan tidak sama dengan perbuatan melawan hukum.

Undang-Undang Nomor 30 Tahun 2014 tentang Administrasi Pemerintahan yang ditetapkan dan diundangkan pada tanggal 17
Oktober 2014 memberikan definisi yang jelas tentang wewenang dan penyalahgunaan kewenangan. Wewenang adalah hak yang dimiliki Badan dan/atau pejabat pemerintah atau penyelenggara negara lainnya untuk mengambil keputusan dan/atau tindakan dalam penyelenggaraan pemerintahan. Pengertian penyalahgunaan kewenangan telah diatur dalam pasal 17 hingga 19 yang meliputi larangan melampaui wewenang, mencampuradukan wewenang dan/atau bertindak sewenangwenang. Penyelenggara negara atau pejabat pemerintah disangkakan melampaui wewenang bila keputusannya melampaui masa jabatan atau batas waktu berlakunya, batas wilayah dan atau bertentangan dengan peraturan perundangundangan. Sedangkan definisi mencampuradukkan kewenangan terjadi bila keputusan atau tindakan di luar cakupan bidang atau materi wewenang dan/atau bertentangan dengan tujuan wewenang. Penyelenggara negara atau pejabat pemerintah dapat disangkakan bertindak sewenang-wenang bila tindakannya tanpa dasar kewenangan dan/atau bertentangan dengan putusan pengadilan yang berkekuatan hukum tetap. Setiap keputusan atau tindakan penyelenggara negara atau pejabat pemerintah dikategorikan adalah penyalahgunaan wewenang bila telah diuji oleh Pengadilan (PTUN) dan telah memiliki kekuatan hukum tetap. Menurut Krisna Harahap (2014) UU Administrasi Pemerintahan secara jelas dan nyata menghambat pemberantasan korupsi karena 
tidak selaras dengan UU Nomor 31 Tahun 1999

Jo. UU Nomor 20 Tahun 2001 tentang Tindak

Pidana Korupsi khususnya unsur perbuatan melawan hukum (pasal 2) dan unsur penyalahgunaan kewenangan (pasal 3) karena hakim tindak pidana korupsi tidak dapat lagi secara langsung dan mandiri menerjemahkan pembuktian unsur penyalahgunaan kewenangan dan pembuktian penyalahgunaan kewenangan menjadi kewenangan absolut hakim PTUN.

\section{Audit Investigasi}

Audit investigasi atau akuntansi forensik merupakan disiplin ilmu yang masih berinduk kepada ilmu akuntansi atau auditing. Terdapat dua kata kunci dalam disiplin ilmu ini yaitu audit atau akuntansi dan investigasi atau forensik. Arens et al (2005) mendefinisikan audit sebagai bagian pengumpulan dan evaluasi terhadap bukti-bukti yang dilakukan oleh orang yang kompeten dan independen untuk menentukan dan melaporkan tingkat kesesuaian antara kondisi yang ditemukan dan kriteria yang ditetapkan. Sedangkan untuk sektor publik atau pemerintah, I Gusti Agung Rai ${ }^{15}$ (2008) mendefinisikan audit sektor publik sebagai kegiatan yang ditujukan terhadap entitas yang menyediakan pelayanan dan penyediaan barang yang pembiayaannya berasal dari penerimaan pajak dan penerimaan lainnya yang ditujukan untuk membandingkan antara kondisi yang ditentukan dan kriteria yang ditetapkan.

Akuntansi forensik atau audit investigasi merupakan disiplin ilmu yang berasal dari ilmu akuntansi atau audit dan dikolaborasi dengan unsur disiplin ilmu hukum. Menurut Hopwood et $\mathrm{al}^{16}$ (2009) forensic accounting merupakan :

Tommie and Aaron ${ }^{17}$ (2010) memberikan pengertian tentang Forensic Accounting refers to the comprehensive view of fraud investigation . . that includes preventing fraud and analyzing antifraud control . . include the gathering of nonfinancial information such as interview of all related parties to a fraud when applicable. . deals with the relation and application of financial fact to legal problem.

Sedangkan D Larry Crumbley dalam T M Tuanakotta (2007) mendefinisikan akuntansi forensik sebagai akuntansi yang akurat untuk tujuan hukum. Hal ini berarti akuntansi yang dapat bertahan dalam kancah perseteruan selama proses persidangan atau dalam proses peninjauan judisial atau administratif. Lebih lanjut Tuanakotta menjelaskan bahwa konsepkonsep auditing dan akuntasi diadopsi dari Amerika Serikat sedangkan hukum Indonesia khususnya pidana dan hukum acara pidana bersumber dari hukum Belanda yang menginduk dari hukum Napoleonic. Untuk itu auditor investigatif perlu memahami kedua ilmu tersebut dan bila diperlukan dapat meminta pendapat kepada ahli tertentu khususnya yang berkaitan dengan hukum pidana atau hukum acara pidana.

Diperlukan kompetensi dan independensi bagi seorang akuntan forensik atau auditor investigatif. Kecakapan profesional atau kompetensi menurut Wahyudin Nor (2013) berarti seseorang yang memiliki pengetahuan dan perilaku etis dalam menjalankan pekerjaannya. Pengetahuan diperoleh melalui 
pendidikan, pelatihan, keahlian, keterampilan dan pengalaman. Memiliki kompetensi tidak berarti menguasai berbagai disiplin ilmu. Bila auditor tidak memiliki pengetahuan yang mencukupi untuk suatu disiplin ilmu dalam melaksanakan pemeriksaan, maka diharapkan dapat berkolaborasi dengan ahli dari disiplin ilmu lain.

\section{Tujuan Audit Investigasi}

Terdapat perbedaan yang cukup mendasar tentang tujuan pelaksanaan audit investigasi yang diatur oleh BPK dengan tujuan audit investigasi yang berlaku bagi dunia profesi audit atau akuntansi forensik. Menurut Peraturan BPK No 1 Tahun 2007 tentang Standar Pemeriksaan Keuangan Negara, audit invetigatif merupakan salah satu jenis audit yang dilaksanakan untuk tujuan tertentu. Tujuan audit investigasi adalah untuk memberikan 'simpulan' atas suatu hal yang diperiksa yang dapat bersifat eksaminasi, reviu atau prosedur yang disepakati. Dua faktor penting dalam audit investigasi adalah tujuan yang ingin dicapai yaitu memberikan 'simpulan atau pendapat' dan kriteria yang dipergunakan sebelum dilakukan analisa lebih jauh.

Hopwood et al (2009) menyatakan bahwa secara umum terdapat dua jenis jasa yang dapat disediakan oleh akuntan forensik yaitu Investigative Services (IS) dan Litigation Services (LS). Kedua aktifitas jasa tersebut memiliki perbedaan yang mendasar, yaitu bahwa

Copyright @ 2017 AKRUAL: Jurnal Akuntansi
'IS may or may not lead to courtroom testimony'. . . IS function of searching for evidence that support an objective and communicate the result of the search . . . Fraud accountant should carefully maintain working paper that document facts only not opinions' while LS recognise the role of the accountant as 'expert', consultant or other role.

Tommie and Aaron ${ }^{21}$ (2010) memiliki

penjelasan yang tidak jauh berbeda bahwa

'for organizational fraud, the objective of investigation is to determine whether a fraud has occurred or is occurring and to determine who the fraudster. In litigation support, the objective is determine by the client. . . . fraud accountant develops a plan to gather sufficient and competent evidence never make a claim of innocence or guilt on the part of a suspect, just the fact'.

Frank et $\mathrm{al}^{22}$ (1990) menyatakan bahwa an investigative accountant explore the fact of a case without assumptions and searches for answers to questions, keeping in mind possible criminal motives . . . investigative acountant operates as part of substantive law, which governs whether evidence is sufficient to prove a criminal violation.

Albrecht et al ${ }^{23}$ (2009) menyatakan bahwa audit investigasi bersifat komplek dan merupakan masalah sensitif dengan tujuan to find the truth to determine whether the symptoms observed actually represent fraud or whether they represent unintentional errors or other factors as well as the who, why, how, when dan where the elements of frauds.

Sedangkan salah satu auditor ahli Indonesia T M Tuanakotta (2007) menyatakan bahwa (audit) investigasi secara sederhana didefinisikan sebagai upaya pembuktian dengan memperhatikan ketentuan hukum (acara) yang berlaku dan pembuktian terjadi atau berakhir di pengadilan. Pemeriksa fraud harus menolak memberikan 'pernyataan' bahwa hasil 
pemeriksaannya membuktikan ada atau tidak ada fraud. Pemeriksa fraud berupaya untuk membuktikan fraud terjadi dan hanya pengadilan yang mempunyai kewenangan untuk menetapkan hal itu.

Istilah investigasi, khususnya di bidang keuangan negara, dalam hukum pidana dan hukum acara pidana di Indonesia tidak memiliki arti yang spesifik. Hukum acara pidana Indonesia tidak mengenal istilah investigasi tetapi mempergunakan norma penyelidikan dan penyidikan. Mengutip perundangan tentang hukum acara pidana, Andi Hamzah (2006) menjelaskan bahwa penyelidikan merupakan serangkaian tindakan penyelidik (polisi) untuk mencari dan menemukan suatu peristiwa yang diduga sebagai tindak pidana guna menentukan dapat atau tidaknya dilakukan penyidikan menurut acara yang diatur menurut undangundang ini. Menurut Andi Hamzah penyelidikan merupakan tindakan untuk mendahului penyidikan dan merupakan salah satu dari tujuh tahap acara pidana yang berarti mencari 'kebenaran'.

\section{HASIL PENELITIAN}

Salah satu perbedaaan mendasar antara Perpres RI Nomor 40 Tahun 2014 tentang Perubahan atas Perpres RI 71 Tahun 2012 dengan Perpres RI Nomor 71 tentang Penyelenggaraan Tanah bagi Pembangunan untuk Kepentingan Umum adalah batasan tentang luas tanah yang dapat diperoleh secara langsung baik melalui jual beli, tukar menukar maupun cara lain yang disepakati oleh kedua belah pihak. Perpres RI Nomor 71 Tahun 2012 memberi batasan luas adalah maksimal 1 hektar sedangkan Perpres RI Nomor 40 Tahun 2014 memberi batasan luas adalah maksimal 5 hektar. Untuk kasus RS Sumber Waras, pihak BPK 'berpendapat' bahwa Perpres Nomor 40 Tahun 2014 belum dapat dijadikan dasar dalam proses Penyelenggaraan Tanah bagi Pembangunan untuk Kepentingan Umum karena belum memiliki Petunjuk Teknis dalam bentuk Peraturan Kepala BPN.

\section{a. Kelemahan Pelaksanaan Audit Investigasi RS Sumber Waras}

Audit investigasi akan memiliki nilai tambah yang sangat bermanfaat bagi penegak hukum ketika hasil audit dapat ditindaklanjuti menuju arah pemidanaan atau litigasi. Namun patut menjadi perhatian bagi para auditor investigatif bahwa proses litigasi atau pemidanaan berbeda dengan proses audit investigasi. Dalam kasus Pembelian RS Sumber Waras, dapat diindikasikan bahwa tujuan investigasi yang ingin dicapai adalah untuk mendukung langkahlangkah penegakan hukum khususnya pengungkapan dugaan tindak pidana korupsi dalam proses pembelian RS Sumber Waras karena audit investigatif tersebut adalah atas permintaan resmi KPK.

Standar audit untuk memeriksa pembelian yang bersumber dari uang negara baik sebagian maupun seluruhnya telah diatur secara rinci dan jelas dalam Peraturan BPK No 1 Tahun 2007 tentang Standar Pemeriksaan Keuangan Negara 
(SPKN). Standar umum merupakan standar yang wajib diikuti untuk setiap jenis pemeriksaan yang dilakukan oleh auditor pemerintah termasuk audit tujuan tertentu atau audit investigasi. Standar umum mensyaratkan agar auditor memiliki kecakapan profesional yaitu menggunakan sendiri atau menggunakan pihak luar yang memiliki pengetahuan, keahlian dan pengalaman tertentu seperti ahli ilmu statistik, ilmu komputer atau ilmu hukum.

Standar umum audit tidak menghalangi penggunaan tenaga ahli di luar ilmu pengetahuan tentang akuntansi atau audit. Standar umum mewajibkan agar tenaga ahli di luar institusi auditor yang dipergunakan oleh auditor memiliki persyaratan bahwa ahli tersebut memiliki kualifikasi dalam bidang keahliannya. Di samping memiliki kualifikasi, tenaga ahli ekternal tersebut juga harus menjaga independensinya selama proses audit investigasi berlangsung.

Selama proses audit investigatif kasus RS Sumber Waras, auditor BPK telah berhasil mengidentifikasi berbagai penyimpangan sepanjang tahapan proses pengadaan. Berbagai penyimpangan yang meliputi seluruh aspek tahapan dalam proses pengadaan tanah untuk pembangunan bagi kepentingan umum yaitu tahapan perencanaan, penganggaran dan pembentukan tim pengadaan tanah, penentuan harga dan tahapan proses serah terima lahan berhasil diidentifikasi oleh auditor BPK.
Simpulan audit investigasi BPK tentang pembelian RS Sumber Waras oleh BTP selaku Gubernur DKI memiliki kelemahan dalam penggunaan kecakapan profesional. Auditor investigatif BPK 'berpendapat' bahwa kriteria yang dipergunakan untuk mengaudit pembelian RS Sumber Waras adalah Peraturan Presiden Nomor 71 Tahun 2012 tentang Penyelenggaraan Tanah bagi Pembangunan untuk Kepentingan Umum dan petunjuk teknisnya yaitu Peraturan Kepala Badan Pertanahan Nasional nomor 5 tahun 2012 tentang Petunjuk Teknis Pelaksanaan Pengadaan Tanah. Auditor investigatif BPK 'berpendapat' bahwa Perpres No 40 Tahun 2014 tentang Perubahan atas Perpres Nomor 71 Tahun 2012 tidak dapat dijadikan kriteria karena belum memiliki petunjuk teknis pelaksanaan kegiatan dalam bentuk Peraturan Kepala BPN walaupun telah diundangkan pada tanggal 24 April 2014. Perbedaan mendasar dari Perpres Nomor 40 Tahun 2014 dan Perpres No 71 Tahun 2012 adalah mengenai luas tanah yang dapat diperoleh langsung baik melalui jual-beli, pertukaran atau cara lain yang disepakati. Perpres Nomor 40 Tahun 2014 memberikan lampu hijau mengenai luas tanah yang dapat diperoleh secara langsung adalah maksimal 5 hektar sedangkan Perpres No 71 Tahun 2012 adalah maksimal 1 hektar.

Kelemahan mendasar dalam proses audit investigasi kasus RS Sumber Waras secara umum terbagi menjadi dua. Pertama adalah terkait dengan tujuan audit investigatif yang bertujuan untuk memberikan 'simpulan' tentang 
sesuatu yang diperiksa sehingga dalam proses audit investigatif tercampur antara pencarian fakta-fakta dengan pendapat yang dikeluarkan oleh para auditor investigatif. Dikarenakan permintaan audit investigatif oleh KPK ditujukan untuk kepentingan 'penyelidikan' dugaan TPK Pembelian RS Sumber Waras maka selayaknya auditor investigatif BPK berperan hanya sebagai pihak yang mengumpulkan faktafakta dan bukti-bukti yang berkaitan dengan proses pembelian RS Sumber Waras oleh BTP selaku Gubernur DKI sebagaimana yang telah ditetapkan dan dipraktekkan dalam standar profesional auditor investigatif .

Kelemahan kedua dari pelaksanaan audit investigatif RS Sumber Waras adalah penggunaan 'pendapat' oleh auditor investigatif BPK tentang penerapan atau pemberlakuan Perpres Nomor 40 Tahun 2014 yang merupakan perubahan atas Perpres No 71 Tahun 2012. Penulis berpandangan bahwa seorang auditor tidak memiliki kecukupan kecakapan profesional di bidang hukum karena minimnya pengetahuan, keahlian dan pengalaman untuk memberikan 'pendapat' tentang penerapan atau pemberlakuan sebuah Peraturan Presiden karena bukan kompetensi inti seorang auditor. Standar audit meminta kepada auditor agar mempergunakan tenaga ahli yang berkompeten di bidang yang bersangkutan dan mampu bersikap independen.

Dalam kasus pembelian RS Sumber Waras, maka selayaknya auditor meminta 'pendapat' atau 'pertimbangan' hukum tentang penerapan atau pemberlakuan Perpres No 40 Tahun 2014 kepada ahli hukum khususnya ahli hukum administrasi negara dan ahli hukum pidana. Karena standar umum dalam proses audit investigasi pembelian RS Sumber Waras tidak diimplementasikan secara baik maka kesimpulan yang diambil oleh tim auditor investigatif yang menyebutkan terjadi 'penyimpangan yang sempurna' terkesan overconfidence walaupun tanpa didukung pertimbangan atau pendapat ahli di bidang hukum mengenai penerapan atau pemberlakuan Perpres No 40 Tahun 2014 yang mengubah batasan luas tanah yang boleh diperoleh secara langsung yaitu 5 hektar dari sebelumnya 1 hektar sebagaimana diatur dalam Perpres No 71 Tahun 2012 berikut petunjuk teknisnya yaitu Peraturan Kepala BPN nomor 5 Tahun 2012.

\section{b. Tidak Terpenuhinya Seluruh Unsur dalam Pasal 2 dan Pasal 3}

Secara nyata dan jelas bahwa pembelian RS Sumber Waras telah melanggar berbagai prosedur yang ditetapkan dalam Perpres baik Nomor 71 Tahun 2012 maupun Perpres Nomor 40 Tahun 2014. Pengecualian pelanggaran tersebut adalah tentang batasan luas lahan yang dapat diperoleh secara langsung yaitu 5 hektar. Akibat diperbolehkannya membeli tanah secara langsung dengan luas maksimal 5 hektar, luas tanah RS Sumber Waras yang dibeli adalah sekitar 3,64 hektar, berdasarkan Perpres No 40 Tahun 2014 maka unsur tentang perbuatan melawan hukum pada pasal 2 tidak terpenuhi. 
Pasal lain yang dapat disangkakan kepada

BTP adalah penyalahgunaan kewenangan atau sarana untuk menguntungkan diri sendiri atau orang lain sebagaimana diatur dalam pasal 3 . Untuk menerapkan pasal 3 maka unsur penyalahgunaan kewenangan, sarana atau kesempatan harus dapat dibuktikan. RS Sumber Waras dimiliki oleh Pemda DKI melalui pembelian yang dibayar lunas pada tanggal 31 Desember 2014 dimana UU Administrasi Pemerintahan telah berlaku karena diundangkan pada tanggal 17 Oktober 2014. Untuk memperoleh bukti yang cukup bahwa BTP telah melakukan penyalahgunaan kewenangan maka sesuai dengan UU Administrasi Pemerintahan, KPK mengajukan pengujian kepada PTUN untuk membuktikan bahwa BTP telah melakukan penyalahgunaan kewenangan dan diperoleh keputusan hakim PTUN yang berkekuatan hukum tetap (in kracht). Panjangnya prosedur dan rentang waktu yang lama untuk menetapkan sesorang sebagai tersangka penyalahgunaan kewenangan telah diperkirakan oleh Prof Dr Krisna Harahap bahwa UU Administrasi Pemerintahan telah memperpanjang prosedur dan membatasi kemandirian hakim tindak pidana korupsi dalam membuktikan unsur penyalahgunaan kewenangan.

PEMBAHASAN

\section{Gambaran dan Analisis Data}

Dian Cahyaningrum (Juni 2016) menguraikan secara ringkas kronologis kasus pengadaan RS
Sumber Waras oleh BTP. Lahan RS Sumber Waras seluas $69.888 \mathrm{~m} 2$ pada mulanya merupakan 1 (satu) hamparan tanah dengan 1 (satu) sertipikat, 1 Nomor Objek Pajak (NOP), dan 1 (satu) Nilai Jual Objek Pajak (NJOP). Pada tahun 1970 lahan dipecah menjadi 2 (dua) sertipikat, masing-masing dengan luas 33.478 m2 (Sertipikat Hak Milik) dan 36.410 m2 (Hak Guna Bangunan). Pemecahan sertipikat tersebut tidak diikuti dengan pemecahan NOP dan Surat Pemberitahuan Pajak Terutang Pajak Bumi dan Bangunan (SPPT PBB). Dengan demikian NOP dan SPT PBB kedua sertipikat tersebut masih menjadi satu. Alamat lahan pada sertipikat induk (sebelum dipecah) adalah Jalan Kyai Tapa, sesuai dengan lokasinya yang berada di pinggir Jalan Kyai Tapa. Alamat yang tercantum pada 2 sertipikat hasil pemecahan secara otomatis mengikuti alamat sertipikat induk, yaitu Jalan Kyai Tapa. Namun faktanya, lahan atau sertipikat yang berbatasan langsung dengan Jalan Kyai Tapa adalah sertipikat SHM seluas $33.478 \mathrm{~m} 2$. Sedangkan lahan/sertipikat HGB seluas $36.410 \mathrm{~m} 2$ yang dibeli Pemprov DKI Jakarta tidak bersinggungan (tidak mempunyai akses) dengan Jalan Kyai Tapa meskipun alamat pada sertipikatnya ada di Jalan Kyai Tapa. Tanah HGB yang dibeli Pemprov DKI Jakarta batas utara Jl. Tomang Utara dan sebelah selatan berbatasan dengan RS Sumber Waras.

Pada tanggal 27 Juni 2014, pihak YKSW atau RS Sumber Waras berkirim surat kepada Plt. Gubernur DKI (Basuki Tjahaya Purnama) 
sebagai tindak lanjut pertemuan Direktur Umum

RS Sumber Waras dengan Plt. Gubernur DKI tanggal 6 Juni 2014. Surat tersebut menyatakan kesediaan pihak YKSW untuk menjual tanah seluas $36.410 \mathrm{~m} 2$ dengan harga $\mathrm{Rp} 20.755 .000$ per m2, sesuai NJOP tanah di Jl. Kyai Tapa. Pada tanggal 7 Juli 2014, YKSW kembali menulis surat penawaran dengan NJOP Rp20.755.000/m2, total Rp755.689.550.000. Dalam surat tersebut diinformasikan, YKSW masih terikat Perjanjian Pengikatan Jual Beli per tanggal 14 November 2013 dengan PT Ciputra Karya Utama (CKU). Dalam Akta Perjanjian Pengikatan Jual Beli (APPJB) tersebut harga tanah per meter persegi adalah Rp15.500.000/m2, sehingga total harga tanah tersebut Rp564.355.000.000. Meskipun YKSW masih terikat dengan PT CKU dan lebih mahal Rp191.334.550.000, Plt. Gubernur Ahok memerintahkan Kepala Bappeda melalui disposisinya tanggal 8 Juli 2014 untuk dianggarkan. Pemprov DKI Jakarta membayar pembelian lahan secara tunai dengan menggunakan cek Bank DKI sebesar Rp755.689.550.000 pada tanggal 31 Desember 2014, malam hari pukul 19.00 WIB.

Harga pembelian Pemprov DKI Jakarta sebesar Rp20.755.000/m2 dengan total Rp755.689.550.000 dinilai sangat mahal karena lebih mahal dari harga pembelian PT CKU, mengingat NJOP di Jl. Tomang Utara hanya sebesar Rp7.445.000/m2. PT CKU bersedia membeli dengan harga tersebut apabila peruntukan tanahnya dapat diubah dari Suka Sarana Kesehatan menjadi komersial. Apabila tanah tidak bisa diubah komersial maka APPJB batal. Selisih harga pembelian antara Pemprov DKI Jakarta dan PT CKU sebesar Rp191.3 miliar inilah yang diindikasikan oleh BPK sebagai kerugian negara/daerah.

Pihak Pemda DKI diduga telah melanggar ketentuan mengenai proses pembelian RS Sumber Waras yang meliputi tahap perencanaan, penganggaran dan pembentukan tim pengadaan lahan RS Sumber Waras. Proses penentuan harga dan tahapan serah terima lahan diduga juga telah disimpangi oleh pihak Pemda DKI sehingga menimbulkan kesimpulan bagi pihak BPK selaku auditor bahwa penyimpangan proses pengadaan lahan RS Sumber Waras telah sempurna. Kriteria yang dipergunakan oleh pihak BPK dalam melakukan proses audit investigatif adalah Undang-Undang Nomor 2 Tahun 2012 tentang Pengadaan Tanah bagi Pembangunan untuk Kepentingan Umum dan Peraturan Presiden RI Nomor 71 Tahun 2012 tentang Penyelenggaraan Tanah bagi Pembangunan untuk Kepentingan Umum berikut revisinya yaitu Perpres RI Nomor 40 Tahun 2014 tentang Perubahan atas Perpres RI Nomor 71 Tahun 2012 tentang Penyelenggaraan Tanah bagi Pembangunan untuk Kepentingan Umum.

Kesimpulan sementara hasil penyelidikan KPK mengindikasikan bahwa belum ditemukan bukti permulaan yang cukup terhadap dugaan tindak pidana korupsi di kasus RS Sumber 
Waras. Kesimpulan sementara tersebut disampaikan oleh Pimpinan KPK saat dilakukan Rapat Dengar Pendapat dengan DPR pada tanggal 15 Juni 2016. Unsur perbuatan melawan hukum atau penyalahgunaan kewenangan dalam dugaan tindak pidana korupsi kasus RS Sumber Waras belum ditemukan karena pihak KPK berpedoman pada Perpres RI Nomor 40 Tahun 2014 tentang Perubahan atas Perpres RI Nomor 71 Tahun 2012 tentang Penyelenggaraan Tanah bagi Pembangunan untuk Kepentingan Umum.

\section{KESIMPULAN DAN SARAN}

Berdasarkan audit tujuan investigatif BPK tentang RS Sumber Waras, secara nyata dan jelas bahwa Gubernur DKI tidak mengimplementasikan governance yang baik dan melakukan perbuatan yang tidak patut dalam proses pembelian RS Sumber Waras. Namun demikian governance yang buruk dan ketidakpatutan tidak secara otomatis menjadi dugaan perbuatan tindak pidana korupsi ketika unsur-unsur dalam pasal, khususnya pasal 2 dan 3, yang mengatur perbuatan tindak pidana korupsi yang berkaitan dengan perbuatan melawan hukum atau penyalahgunaan kewenangan tidak terpenuhi.

Terdapat perbedaan mendasar antara tujuan audit tertentu yang telah diatur dalam Peraturan BPK No 1 Tahun 2007 tentang SPKN dengan standar profesi tentang audit investigasi yang berlaku internasional. Audit investigasi merupakan salah satu jenis audit dalam Audit Tujuan Tertentu yang memiliki tujuan audit untuk 'menyimpulkan' atau memberikan 'pendapat' tentang suatu hal yang diperiksa baik melalui eksaminasi, reviue maupun prosedur yang disepakati. Berdasarkan standar profesi yang berlaku internasional, audit investigasi bertujuan untuk mengumpulan fakta-fakta dan mencari serta memperoleh bukti-bukti bukan 'asumsi' atau 'pendapat' yang dapat membantu pengungkapan dugaan tindak pidana atau materi bahan gugatan dalam perkara perdata.

Audit investigasi khususnya atas permintaan aparat penegak hukum memiliki orientasi akan dibawa menuju arah pemidanaan atau litigasi. Agar tujuan tersebut tercapai maka diharapkan agar standar audit baik yang bersifat umum maupun standar audit tujuan tertentu. dapat diimplementasikan sesuai dengan tahapan atau prosedur audit. Pengabaian penerapan standar audit dapat berdampak secara langsung terhadap tujuan audit yang ingin dicapai. Dalam kasus pembelian RS Sumber Waras, ketika seorang auditor tidak memiliki kecakapan profesional yang cukup dalam bidang hukum dan melompati kompetensi yang dimiliki seorang ahli hukum, khususnya hukum administrasi negara, berdampak negatif secara langsung terhadap simpulan audit investigatif.

Untuk memperkuat aspek investigasi yang berkaitan dengan pengelolaan keuangan negara dalam rangka membantu proses penegakan hukum khususnya pidana korupsi maupun proses gugatan ganti kerugian, maka penulis mengusulkan agar : 
1. Dilakukan revisi terhadap Peraturan BPK Nomor 1 Tahun 2007 tentang Standar Pemeriksaan Keuangan Negara khususnya yang berkaitan dengan audit investigasi. Direkomendasikan agar audit investigasi merupakan salah satu Jenis Pemeriksaan dan bukan menjadi salah satu jenis audit tujuan tertentu. Alasan yang mendasari adalah bahwa tujuan audit investigasi adalah berkaitan dengan pencarian dan pengumpulan fakta-fakta dan bukti-bukti yang berkaitan dengan penegakan hukum pidana maupun untuk kepentingan materi gugatan dalam perkara hukum perdata. Dalam proses audit investigatif tidak diperlukan 'pendapat' atau 'opini' dari para auditor investigatif. Dalam proses investigasi dengan cara audit, para auditor tidak diperankan sebagai pihak yang memberikan keterangan ahli tetapi meraka adalah salah satu pihak yang bertindak pada awal proses investigasi yaitu pengumpulan fakta dan bukti yang dapat membantu pengungkapan dugaan tindak pidana atau perumusan materi gugatan.

2. Meningkatkan profesionalisme para auditor investigatif khususnya dalam hal membedakan peran antara peran sebagai auditor investigasi yaitu bagian dari proses investigasi dengan peran sebagai ahli yang berhak mengeluarkan opini atau pendapat dalam proses membantu pengungkapan dugaan tindak pidana atau perumusan materi gugatan. Sebagai auditor investigasi, harus disadari bahwa selama terlibat dalam proses awal pengungkapan dugaan tindak pidana, maka yang diunggulkan adalah kemampuan untuk mengungkapkan fakta-fakta dan mencari serta memperoleh bukti-bukti untuk mendukung pengungkapan dugaan tindak pidana. Peran berbeda akan dilaksanakan oleh para auditor bilamana diperlukan sebagai 'Ahli' dalam proses pengungkapan dugaan pidana. Seorang 'ahli' akan diminta tentang 'pendapat' keahliannya, misalnya menghitung kerugian negara, yang merupakan salah satu dari alat bukti dalam proses pidana tanpa terlibat dalam proses investigasi.

Tulisan ini difokuskan pada peran dan fungsi akuntansi forensik atau audit investigasi dalam mengungkap kejahatan korupsi khususnya dalam kasus pembelian RS Sumber Waras oleh BTP pada tahun 2014. Peran audit investigasi tersebut adalah sebagai bagian awal proses investigasi atau penyelidikan dalam rangka mencari fakta (bukan opini) atau bukti permulaan yang cukup untuk memenuhi unsur perbuatan melawan hukum atau penyalahgunaan kewenangan dengan catatan unsur memperkaya atau menguntungkan BTP atau orang lain belum ditemukan. Bila di kemudian hari penyelidik atau penegak hukum menemukan bukti permulaan yang cukup tentang adanya unsur memperkaya atau menguntungkan BTP atau orang lain dalam proses pembelian RS Rumber 
Waras maka peran audit investigasi akan berubah menjadi saksi fakta atau memberikan keterangan (pendapat) ahli tentang kerugian negara akibat praktek dugaan korupsi pembelian RS Sumber Waras oleh BTP selaku Gubernur DKI Jakarta dengan persyaratan diperoleh putusan tetap dari Pengadilan PTUN tentang unsur perbuatan penyalahgunaan kewenangan.

\section{DAFTAR PUSTAKA}

Albrecht, W Steve., Albrecht Conan C., Albrecht, Chad O., \& Zilbelman, Mark F. 2009. Fraud Examination. 3rd Edition. South Western Cengage Learning, Mason USA.

Andi Hamzah, 2004. Hukum Acara Pidana Indonesia. Jakarta Penerbit Sinar Grafika. Berita Resmi Statistik Nomor 21/02/Th.XVIII. 22 Februari 2016 Badan Pusat Statistik.

Arens, Alvin A., Elder, Radl J., \& Beasly, Mark S. 2005. Auditing and Assurance Service. Prentice Hall, New Jersey

Dian Cahyaningrum. 2016. Silang Pendapat BPK dan KPK dalam Kasus Sumber Waras. Info Singkat Hukum, Vol VIII, No 12/II/P3DI/Juni

Frank, Peter B., Wagner, Michael J., \& Loeil, Roman L. 1990. Litigation Service Handbook: The Role of The Accountant as Expert Witness. John Willey and Son. USA.

Hopwood, William S., Kreiner, Jay J., \& Young, Goerge F. 2009. Forensic Accounting: International Edition. Singapore.

Kuncoro, Mudradjad. 2009. Metode Riset untuk Bisnis dan Ekonomi: Bagaimana Meneliti dan Menulis Tesis. Jakarta: Penerbit Erlangga.

Nor, Wahyudin. 2011. Peran Kompetensi dan Independensi Auditor dalam Meningkatkan Kualitas Audit Keuangan Negara, Jurnal Ilmiah Akuntansi dan Bisnis, Vol 6 No 2 Juli.
Peraturan BPK Nomor 1 Tahun 2007 tentang Standar Pemeriksaan Keuangan Negara

Peraturan Presiden Nomor 71 Tahun 2012 tentang Pengadaan Tanah bagi Pembangunan untuk Kepentingan Umum

Peraturan Presiden Nomor 40 Tahun 2014 tentang Perubahan Peraturan Presiden Nomor 71 Tahun 2012 tentang Pengadaan Tanah bagi Pembangunan untuk Kepentingan Umum

Rai, I Gusti Agung. 2008. Audit Kinerja pada Sektor Publik : Konsep, Praktik dan Studi Kasus. Jakarta: Penerbit Salemba Empat,

Singleton, Tommie W., \& Singleton, Aaron J. 2010. Fraud Auditing and Forensic Accounting. New Jersey: John Willey and Son.

Soekanto, Soerjono \& Mamudji, Sri. 2011. Penelitian Hukum Normatif: Suatu Tinjauan Singkat. Jakarta: Penerbit PT Raja Grafindo Persada.

Suliyanto. 2006. Metode Riset Bisnis. DI Yogyakarta: Penerbit ANDI

Tuanakotta, Theodorus M. 2007. Akuntansi Forensik dan Audit Investigatif. Jakarta: Departemen Akuntasi FEUI, LP FEUI.

Undang-Undang No 31 Tahun 1999 Jo UndangUndang No 20 Tahun 2001 tentang Tindak Pidana Korupsi

Undang-Undang No 30 Tahun 2014 tentang Administrasi Pemerintahan 